\title{
Exploratory Epidemiological Study on Porcine Circovirus Type 2 Infection and Postweaning Multisystemic Wasting Syndrome in the Czech Republic
}

\author{
Radek Ficek ${ }^{1}$, Ivan Pšikal ${ }^{3}$, Petr Fictum², Jindřiška Bendováa ${ }^{3}$ Eva Kosinová 3 , \\ Radka Smítalová ${ }^{\text {, Miša Škorič }}{ }^{2}$ \\ ${ }^{1}$ Clinic of Pig Diseases, ${ }^{2}$ Department of Pathologic Morphology, Faculty of Veterinary Medicine, \\ University of Veterinary and Pharmaceutical Sciences, Brno, Czech Republic \\ ${ }^{3}$ Veterinary Research Institute, Brno, Czech Republic \\ Received December 3, 2008 \\ September 8, 2009
}

\begin{abstract}
The objective of our study was to diagnose the postweaning multisystemic wasting syndrome (PMWS) and to determine the prevalence of the disease in 33 swine herds in the Czech Republic using the results of laboratory examinations of 100 pigs expressing the signs of wasting at the end of 2007. Microscopic lesions associated with the presence of porcine circovirus 2 (PCV2) antigen were detected in the lymph nodes from 39 of 100 diseased pigs (39\%). Based on individual assessment of severity of microscopic lymphoid lesions associated with high amounts of PCV2 antigen, PMWS was confirmed in 4 out of 39 pigs originating from 3 of 33 herds (9\%). The epidemiological study indicates that PCV2 infections associated with PMWS disease are only sporadically present in the Czech Republic. Subsequently used real time PCR technique confirmed the relation between PMWS status at the individual pig level and PCV2 DNA concentration. PCV2 DNA load in lymph nodes of PMWS-affected pigs were about 3 logs higher than the levels detected in the PMWS-nonaffected group $(P<0.05)$. Other parallel viral infections (PRRSV, PPV) were detected by real time PCR techniques in 21 out of 39 PCV2 infected pigs (54\%). The results of serological examination of blood samples collected during the necropsy of 100 pigs are suggestive of great prevalence of PCV2 infections in pig herds; nevertheless serum samples collected from individual pigs at a single point in time had a low diagnostic value.
\end{abstract}

Swine, epizootiological survey, porcine circovirus, postweaning multisystemic wasting syndrome, porcine parvovirus, PRRSV, ELISA

Porcine circovirus associated diseases (PCVD) have become major health concerns with significant welfare and economic consequences for pig producers and pig meat industry worldwide. Porcine circovirus type 2 (PCV2) is the agent thought to be mainly responsible for development of the post-weaning multisystemic wasting syndrome (PMWS) in pigs (Allan and Ellis 2000). However, PCV2 infections of pigs are also associated with other clinical conditions called porcine dermatopathy and nephritis syndrome (PDNS), porcine respiratory disease complex (PRDC), and reproductive disorders and abortion (Rosell et al. 2000; Segales et al. 2004a). PMWS was first described in Canada in mid 1990s (Clark 1997). The disease was subsequently confirmed in many countries in Europe (Segales et al. 1997; Kennedy et al. 1998; Wallgren et al. 2004; Madec et al. 2000; Allan et al. 1998), North America (Ellis et al. 1998), Asia (Wang et al. 2004) and Japan (Onuki et al. 1999).

The disease occurs predominantly in weaners and growers and usual morbidity rates reaches 4 to $30 \%$ in affected herds and mortality is close to $70-80 \%$ in pigs that develop the full spectrum of symptoms at the peak of the disease. The clinical course of the disease is characterized by gradual loss of weight of piglets, predominantly at the age of 6 to 12 weeks, and irregularly it is accompanied by other symptoms such as dyspnoea, cough, icterus, lymph node enlargement and typical histopathological findings in lymphoid tissues

Address for correspondence:

MVDr. Radek Ficek

University of Veterinary and Pharmaceutical Sciences Brno

Clinic of Pig Diseases

Phone: +420541562435

Palackého 1-3, 61242 Brno, Czech Republic

E-mail: ficekr@vfu.cz

http://www.vfu.cz/acta-vet/actavet.htm 
- systemic lymphadenopathy and associated angiocentric granulomatous lymphadenitis with lymphoid depletion (Krakowka et al. 2000).

Diagnosis of the PMWS in individual pigs is based on the assessment of clinical, histopathological and virus-detection findings according to criteria described by Sorden (2000). The PCV2 antigens or nucleic acid are usually detected by immunohistochemistry or in situ hybridization within lymphoid lesions (Rosell et al. 1999).

Subclinical infections with PCV2 are extensively spread in pig population and individual pigs fulfilling criteria of PMWS diagnosis can also be found in herds of good health and production status (Segales et al. 2003). With regard to the multifactorial character of PMWS, whose clinical manifestation can be influenced by simultaneous occurrence of other pathogenic microorganisms (Pogranichniy et al. 2002) and non-infectious cofactors (Krakowka et al. 2001), it is important to detect PMWS not only in individuals but also on the herd level.

In Europe the first clinical forms connected with circoviral infections in pigs were described in France in 1995 (LeCann et al. 1997), since then the disease spread through other West European countries (Wellenberg and Segales 2006). In that time, the exact impact of PCVD was not known in the Czech Republic but could be assumed, especially when we realize that the outbreaks of PMWS and PDNS, the most common forms of PCVD, were recorded in Central European countries, for example in Hungary in 1999 (Kiss et al. 2000), in Poland in 2000 (Pejsak et al. 2001) and in Croatia in 2002 (Lipej et al. 2005).

The objective of our study was to diagnose PMWS and to determine the prevalence of PMWS in 33 herds of the Czech Republic. Additionally, evidence of PPV and PRRSV infection was assessed in the studied herds.

\section{Materials and Methods}

Study design

The epidemiological survey focused on PCV2 infections in relation to PMWS was carried out in the Czech Republic at the end of 2007. The selection of farms suspected of PMWS and transportation of pigs for laboratory examinations were carried out in collaboration with the "Mevet Ltd." "Sevaron Advisory Ltd." and with veterinary practitioners specialized in pig breeding who were asked by a questionnaire about history data including the health status of pigs and mortality proportions in herds. Selection of pigs for PMWS investigation was effectuated according to progression of clinical signs and death rates in weaners and growers which were most evocative of PMWS-like condition. The selection was oriented to herds with mortality exceeding the regional level by $50 \%$ in accordance with the methodology for PMWS herd case definition (www.pcvd.org).

PMWS investigation included 33 farms with a total number of 18,882 breeding sows located at different sites of the Czech Republic. This number of breeding sows represents approximately $8 \%$ of sow population in the country. Of 33 herds under investigation, 28 practiced the conventional farrow-to-finish production system with piglet weaning at the age of 25 to 28 days, and in 5 herds a two-site system for production of young breeding animals was used. The size of pig herds based on the number of breeding sows ranged from 70 (very small) to 2000 (very large). A total of 100 pigs aged 6 to 12 weeks originated from 33 herds with clinical signs indicative of PMWS were laboratory examined.

The criteria used for the diagnosis of PMWS include the existence of compatible clinical signs, presence of characteristic microscopic lesions in lymphoid tissues and detection of PCV2 within these lesions (Segales and Domingo 2002; Sorden 2000).

From each herd under study, at least three weaned pigs aged 6 to 12 weeks showing suggestive clinical signs of wasting were selected, euthanized and examined by necropsy. The piglets were euthanized by injecting the preparation T-61 ad us.vet. (Embutramidum $200 \mathrm{mg}$, Mebezonii iodidum $50 \mathrm{mg}$, Tetracaini chloridum $5 \mathrm{mg}$ per $1 \mathrm{ml}$ ) in accordance with the current Czech legislation on animal welfare. During necropsy, evaluation of gross lesions and collection of lymph nodes from thoracic and abdominal cavities, and from the subcutaneous inguinal region were accomplished in each pig.

Laboratory examination

Macro- and microscopic evaluation

During necropsy, the external examination was performed including assessment of body conditions. Macroscopic findings were then confronted with histopathological examinations, for which three lymph nodes (superficial inguinal, tracheobronchial, mesenteric) and blood samples were collected. These included microscopic, virological and serological examinations. The same tissues collected from every pig were fixed both in $10 \%$ buffered formalin and snap 
frozen in liquid nitrogen. Tissue samples for virological examinations were stored at $-80{ }^{\circ} \mathrm{C}$ and samples of coagulated blood were centrifuged at $800 \times g$ for 5 min; the obtained serum was stored at $-20{ }^{\circ} \mathrm{C}$.

Microscopic examination involved the evaluation of haematoxylin-eosin (HE) stained tissue sections of lymph nodes (histopathology) and immunostaining (IHC) of cryostat sections from the same lymph nodes. The tissue samples for microscopic examination were dewatered and embedded into paraffin. Subsequently the tissue sections were prepared ( $3 \mu \mathrm{m}$ in thickness), deparaffined and stained by haematoxylin-eosin (HE). Tissue samples for IHC analyses were snap frozen in liquid nitrogen, pulled out after 1 min incubation, covered with parafilm and placed into tubes. Frozen samples were stored at $-80{ }^{\circ} \mathrm{C}$ until further processing in the cryomicrotome (Leica CM-1900). After cutting, the sections were put onto slides and subsequently fixed in acetone for 10 min and stored at $-20{ }^{\circ} \mathrm{C}$ until required for immunostaining.

Immunostaining (IHC) of cryostat sections from the lymph nodes was performed according to the standard operating procedure (Veterinary Science Division, Belfast, UK) using the PCV2 specific monoclonal antibodies F217 2C6-H9-A2 (McNeilly et al. 2001) and rabbit anti-mice conjugate labelled with peroxidase (RabM/HRP, Dako, DK). IHC test in cryocut sections allowed us to assess low, moderate or large amounts of PCV2 antigens.

Real-time PCR detection of PCV2, PPV and PRRSV

PCV2 and PPV DNA were quantified by a duplex PCR method in TaqMan PCR format. Primers and the labelled probe used for DNA quantification of PCV2 were described by Brunborg et al. (2004). Primers and the probe for DNA quantification of PPV were designed based on comparative analysis of porcine parvovirus sequences available in the Gene Bank (http:/www.ncbi.nlm.nih.gov/BLAST/). The forward primer (QG3\#1: 5'-GGAGCGAGCCAACAACACCA-3') and reverse primer (QC3\#2: 5'-GCACAGTTTTCACCAAAGCAGG-3') were designed to amplify a 139 bp region of nonstructural gene NS-1 of PPV. The TaqMan probe (QC4\#P: 5“-Cy5-CCAGATTCAGCAATACGGACACCAAGT- ${ }^{\mathrm{BHQ}}{ }^{2}-3^{\circ}$ ) specific to PPV NS1 gene was labeled with different fluorophores (Cy5 and BHQ2) to permit simultaneous detection of PPV DNA target. Oligonucleotides and probes were synthesized by Generi Biotech (Hradec Králové, Czech Republic). Optimum conditions for carrying out simultaneous detection and quantification of PCV2 and PPV DNA targets were obtained with final concentration of $4.5 \mathrm{mM} \mathrm{MgCl}_{2}, 0.2 \mu \mathrm{M}$ of each PCV2-primer, $0.4 \mu \mathrm{M}$ of each PPV-primer and $0.15 \mu \mathrm{M}$ of each TaqMan probe in $20 \mu \mathrm{l}$ LightCycler 480 Probes Master mixture (Roche). The fluorescence signals in multicolor detection format were monitored in each of 40 cycles at the end of annealingextension incubation at $60{ }^{\circ} \mathrm{C}$ in LightCycler 480 Instrument (Roche), in the range of light spectrum $483-533 \mathrm{~nm}$ for FAM and 615-670 $\mathrm{nm}$ for Cy5 fluorophores.

Total DNA from different examined tissues of pigs $(\sim 1 \mathrm{~g})$ was extracted with NucleoSpin Tissue (Macherey Nagel, Germany) according to the manufacturer's instructions. Concentration of viral DNA was normalized as an average number of copies in $1 \mu \mathrm{g}$ total DNA isolated from a sample. Samples of the isolated DNA were applied to a 96-well plate in duplicates and the standards in triplicates.

Absolute quantification of DNA PCV2 and DNA PPV was carried out using calibration curves generated by means of external standard DNA obtained by cloning of ORF2 gene of PCV2 and NS-1 region of PPV into the plasmid pCR 2.1 (Invitrogene). Standard curves for PCV2 and PPV DNA quantification were generated using 10-fold dilutions of both the linearized recombinant plasmids in the range of $8 \log _{10}$. The real time PCR specificity was further tested with DNA from porcine bacteria and viruses (PCV1/PK15, CCL-33; P. multocida; Pseudorabies herpesvirus) and no positive fluorescence signal was obtained.

Total RNA extraction from all lymph nodes (superficial inguinal, tracheobronchial, mesenteric) collected during necropsy was performed using a QIAamp viral RNA mini kit (Qiagen). Primer and probe combination specific for the European (EU) and the North American (N.A.) PRRSV were described by Opriessnig et al. (2006). The TaqMan probes specific for the European and/or the North American PRRSV were labelled with FAM or VIC fluorophores to allow detection of different PRRSV RNA target sequences in one reaction. For the real-time reverse transcriptase PCR (RT-PCR), QuantiTect probe RT-PCR kit (QIAGEN) was used with the magnesium chloride concentration adjusted to $6 \mathrm{mM}$. Forward and reverse primers and detection probes were used at the concentrations of 400, 400, and $100 \mathrm{nM}$, respectively, for the North American and European PRRSV. The duplex real-time RT-PCR was performed in the LightCycler 480 Instrument (Roche) under the following conditions: 30 min at $50{ }^{\circ} \mathrm{C}, 15 \mathrm{~min}$ at $95{ }^{\circ} \mathrm{C}$, followed by 40 cycles of $15 \mathrm{~s}$ at $94{ }^{\circ} \mathrm{C}$ and $60 \mathrm{~s}$ at $60{ }^{\circ} \mathrm{C}$. Each plate included five progressive 1:10 dilutions of a known TCID $_{50}$ of PRRSV-EU strain (V-501) or PRRSV-N.A. (VOS2878) that served to generate standard curves and to apply colour compensation to correct the spectral overlap between filter combination 465-510 $\mathrm{nm}$ (FAM) and 533-580 $\mathrm{nm}$ (VIC).

\section{ELISA antibodies against PCV2}

Antibodies against PCV2 were detected in porcine sera using indirect ELISA technique with recombinant capsid protein PCV2 produced in a modified form in E. coli cells (Psikal et al. 2006). Known positive and negative samples (Agri-Food and Bioscience Institute, Queen's University Belfast, Northern Ireland, UK) were implicated. The final value of optical density (OD) was calculated by subtracting the OD value in negative control from the OD value in cap antigen. Negative control and limited-positive swine sera $(\mathrm{OD}=\sim 0.250)$ were included in each examination. The contents of antibodies to PCV2 were evaluated according to $\mathrm{S} / \mathrm{P}$ ratio $=$ mean OD sample (S)/mean OD limited-positive control (P). Any sample presenting $\mathrm{S} / \mathrm{P}$ ratio $\geq 0.3$ was considered positive for the presence of antibodies in serum. 
Statistical analysis

Statistical analyses were carried out using ANOVA for Windows software (SPSS ${ }^{\circledR}$ Base 15.0, SPSS Inc., Chicago, IL, USA) to test whether the PCV2 and PRRSV antibody levels and PCV2 genomic load profiles were significantly different according to the PMWS status of individual animals. Values of $p<0.05$ were considered statistically significant.

\section{Results}

Clinical observations and macroscopic findings

External examination of 100 pigs revealed unilateral enlargement of the superficial inquinal lymph node in 8 pigs, bilateral enlargement of inguinal lymph nodes in 14 pigs, and an extreme enlargement of inguinal lymph nodes in 3 pigs. Pathological findings were found in the thoracic cavity and lungs in 66 of the necropsied pigs. The most frequent macroscopic lesions were pneumonia and bronchopneumonia in 57 pigs (89\%), pleuritis in 12 pigs (18\%), pericarditis in 9 pigs (14\%), lack of pulmonary collapse with lobular pattern in 6 pigs $(9 \%)$, and abscesses in 4 pigs $(6 \%)$. Other lesions were described in the abdominal cavity in 73 of the necropsied pigs. The most frequent macroscopic lesions were catarrhal enteritis and enterocolitis (69\%), peritonitis (10\%), and white tiny lesions of grey colour disseminated in kidney parenchyma (5\%). The proportion of serositis was $4 \%$.

Histological and immunohistochemical findings and PMWS classification

The presence of PCV2 antigen was confirmed in 39/100 pigs in 72/300 lymph nodes by IHC. In these pigs, microscopic changes were examined in a total of 117 lymph nodes.

Most PMWS consistent microscopic lesions in 117 examined lymph nodes from 39 pigs were lymphocyte depletion $(40.2 \%)$, histiocytic to granulomatous inflammation $(26.5 \%)$, and purulent and/or chronic lymphadenitis (20.5\%). Cytoplasmic inclusion bodies were observed in $4.3 \%$ of all lymph nodes and were mostly found in connection with severe microscopic changes in lymph nodes with high amounts of PCV2 antigen.

Based on individual assessment of severity of microscopic lymphoid lesions associated with high amounts PCV2 antigen in necropsied pigs, 1 out of 39 pigs showed microscopic lesions characterized by severe lymphoid depletion and severe multifocal to diffuse granulomatous inflammation of all lymphoid tissues under evaluation (Plate VII, Fig. 1A, B). In 3 out of 39 investigated pigs, overall lymphoid lesions were characterized by severe lymphoid depletion and moderate histiocytic inflammation in a restricted number of lymph nodes associated with high amounts of PCV2 antigen. Of other 35 investigated pigs with low amount of PCV2 antigen, moderate changes characterized by mild lymphoid depletion and/or moderate histiocytic inflammation were found in lymph nodes of 28 pigs. The remaining 8 pigs did not show PCV2-associated lymphoid lesions consistent with PMWS.

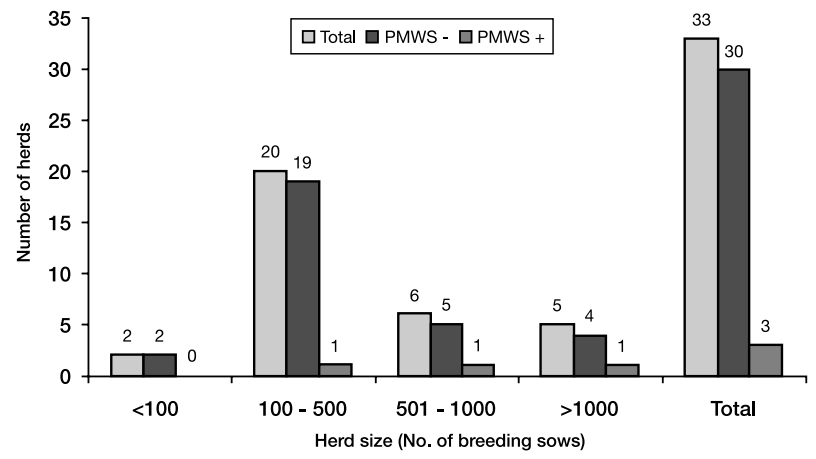

Fig. 2. Relation between PMWS status and the size of pig herds $(\mathrm{n}=33)$. 


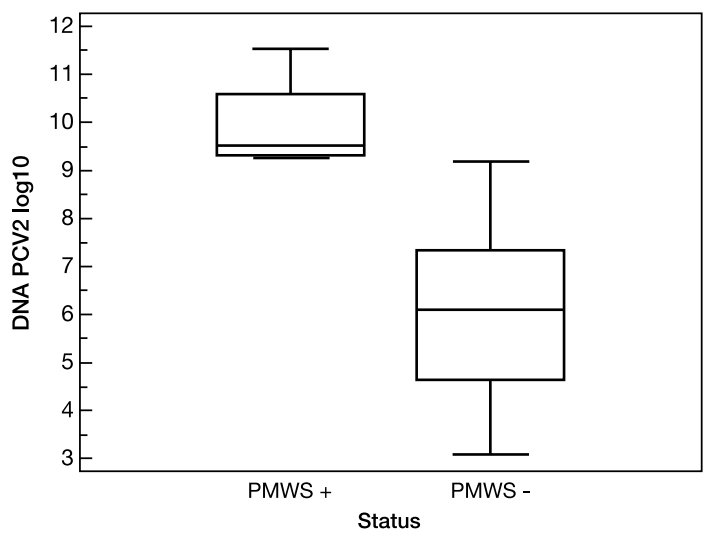

Fig. 3. Mean of DNA PCV2 copy numbers in lymph nodes of necropsied pigs $(n=39)$ classified as PMWS-affected (PMWS+) and PMWS non-affected (PMWS-). Box plots show $\log _{10}$ PCV2/DNA genomic load distribution in pig lymph nodes among PMWS classified groups.

The vertical height of each box represents $25 \%-75 \%$ data range, the horizontal line within each box represents the mean value, and the upper and lower bars denote the largest and smallest values that were determined not to be outlier specimen $(>75 \%)$.

In accordance with clinical signs and pathological findings, PMWS affection was confirmed in four out of 39 pigs examined. These individual pigs were classified as PMWS affected. Other 35 pigs with low amount of PCV2 antigen and with mild microscopic lesions in lymphoid organs were classified as PMWS non-affected.

The group of PMWS affected pigs originated from three herds with clinical manifestation of the wasting syndrome and high mortality (from 12 to $25 \%$ ) exceeded the current level in the region in the age category of weaners and growers by $50 \%$. Relation of the PMWS status in individual pigs and the size of pig herd showed that three farms with PMWS affected pigs practiced the farrow-to-finish system and had 400, 580 and 1900 breeding sows, respectively.

Virological and serological findings

In order to determine whether PRRSV, PPV and PCV2 can interact in naturally acquired PMWS disease, all lymph nodes from the 39 necropsied pigs examined by immunohistochemistry (IHC) were analyzed by fluorogenic polymerase chain reaction for DNA genome templates of PCV2 and PPV (qPCR) and for RNA templates of PRRSV (qRTPCR). Significant differences were observed between mean DNA PCV2 concentrations in lymph nodes from two PMWS-classified pig groups (Fig. 3). PMWS status confirmed by histopathology and immuno-histochemistry at individual pig level corresponded with the mean of $10^{9.5}$ copies of PCV2/DNA templates per $1 \mu \mathrm{g}$ of total DNA isolated from lymph nodes, while the mean concentration values of PCV2 DNA templates in PMWS nonaffected group was significantly lower $(p<0.05)$. The mean of $10^{6.3}$ PCV2/DNA copies was found in 35 PMWS non-affected pigs.

Other parallel viral infections were detected in 21 out of 39 PCV2 infected pigs (54\%) (Table 1). The relation was found between PMWS status at individual pig level and porcine parvovirus (PPV) DNA detection by duplex qPCR. Three out of four PMWS-affected pigs had genomic PPV DNA at least in one lymph node, whilst in the group of 35 PMWS nonaffected pigs PPV DNA was identified in lymph nodes of 6 pigs. There was no significant difference in the mean of PPV DNA load in lymph nodes between PMWS-classified groups, and the concentration of PPV DNA copies ranged from $1.2 \times 10^{1}$ to $8.9 \times 10^{6}$. 
Tab. 1. Concurrent infections of PCV2, PRRSV and PPV.

\begin{tabular}{|l|c|c|c|}
\hline Viruses & No. of pigs (\%) & $\begin{array}{c}\text { No. of pigs in PMWS } \\
\text { affected group }\end{array}$ & $\begin{array}{c}\text { No. of pigs in PMWS non- } \\
\text { affected group }\end{array}$ \\
\hline PCV2+ PRRSV & $12 / 39(31 \%)$ & $0 / 4$ & $12 / 35$ \\
\hline PCV2 + PPV & $9 / 39(23 \%)$ & $3 / 4$ & $6 / 35$ \\
\hline Total & $21 / 39(54 \%)$ & $3 / 4$ & $18 / 35$ \\
\hline
\end{tabular}

PRRS virus of the European genotype was detected using qRT-PCR in 12 PCV2 positive pigs out of 39 examined (31\%), however, all 12 PRRSV positive findings were identified in the group of PMWS non-affected pigs (Table 1).

In this case 4/100 pigs were diagnosed as PMWS positive (clinical signs, pathological lesions, histopathological, immunohistochemical confirmation and qPCR). These PMWSpositive animals came from 3/33 examinated herds. Other 96/100 pigs were classified as PMWS negative.

Serum samples from 100 necropsied pigs were analysed for antibodies against PCV2. No antibodies to PCV2 were found in 5 out of 100 serum samples taken from the necropsied pigs. Other 95 out of 100 serum samples were classified as PCV2 antibodies positive. Differences were recorded among PMWS-classified group in mean levels of ELISA antibodies (cut off S/P level $=0.3$ ). The lower mean level of antibodies to PCV2 was found in the group of 4 PMWS affected pigs (mean of $\mathrm{S} / \mathrm{P}=0.510 \pm 0.420$ ) and the higher mean level of antibodies to PCV2 was found in the group of 96 PMWS non-affected pigs (mean of $\mathrm{S} / \mathrm{P}=0.881 \pm 0.058)$. However, these differences were not significant $(p=0.087)$.

\section{Discussion}

Porcine Circovirus Diseases (PCVDs) remain a major problem internationally. In order to clarify the present situation on PMWS in the Czech Republic, 100 diseased pigs were investigated, of which PCV2 infection was found in 39. The finding of severe histopathological changes, together with immunohistochemical detection of high concentrations of PCV2 antigen in lymphoid tissues of 4 pigs aged 8 to 10 weeks, indicated that the natural course of PCV2 infections could be attributable to PMWS disease described by others (Ellis et al. 1999; Rosell et al. 1999). Those four pigs fulfilling individual criteria of PMWS diagnosis originated from 3 of $33(9 \%)$ herds that reported clinical signs suggestive of wasting accompanied with excessive increase of mortality in weaners and growers. On the other hand, the remaining 30 (81\%) herds with similar anamnestic data did not comply with the accepted criteria for PMWS diagnosis because mild or no characteristic histopathological lesions in lymph nodes of individual pigs were detected at laboratory examination, and only a low concentration of PCV2 antigen was demonstrated using IHC.

Unlike the epizootic form of PMWS described in some countries in late 1990s (Segales et al. 1997; Kennedy et al. 1998), our epidemiological study indicates that PCV2 infections associated with PMWS disease are only sporadically present in the Czech Republic. This is in accordance with the findings of microscopic changes consistent with PMWS which were not as frequent in the lymph nodes of the examined pigs as in the studies of other authors. For example Rosell et al. (2000) found in lymphoid tissues of 455 examined pigs lymphocyte depletion in 407 pigs $(89.5 \%)$, histiocytic inflammation in 354 pigs (78\%) and intracytoplasmic inclusion bodies in $146(32 \%)$ animals. Low frequency of histopathological changes can be influenced by an inadequate selection of clinically affected pigs for laboratory examinations, even in the case of positive findings of PCV2 antigen. Previous studies confirmed that subclinically infected pigs or pigs in a convalescent phase from PMWS may not have typical microscopic lesions or can only 
have very mild ones, and PCV2 antigen or nucleic acid in lymphoid tissues can be detected in a low amount (Quintana et al. 2001).

Classification of PMWS on herd level showed that PMWS cases were diagnosed among pig herds of 100 to 500 breeding sows (5\%), of 501 to 1000 breeding sows $(16.6 \%)$, and with more than 1000 breeding sows (20\%). PMWS was not identified in any herd having less than 100 breeding sows. Higher proportion of PMWS cases among herds with medium and high numbers of sows in the basic herd (501 to 1000 and more than 1000 breeding sows) is given by lower representation of such herds in the study. In accordance with the report of Rose et al. (2003), we suggest that PMWS outbreaks in larger herds are associated with more risk factors which increase the probability of developing the condition. On the other hand, the prevailing number of herds suspected of PCVD, where the PMWS status has not been confirmed, can be connected with an insufficient number of samples needed, or the pigs selected for laboratory analyses were not in the initial phase of clinical signs of wasting. Pathological assessment of body condition shows that many of the pigs selected for necropsy were in terminal health condition and samples for microscopic examinations by IHC might be false negative. Recent studies have shown that the diagnosis of PMWS and other affections connected with PCV2 infections in pigs is more reliable when applied to larger groups of pigs (Sarli et al. 2008).

The causes of different clinical expression of PMWS have not yet been clarified, however, their association with other infectious and non-infectious factors was suggested (Pogranichniy et al. 2002; Krakowka et al. 2007; Kyriakis et al. 2002; Pallares et al. 2002) as well as the impact of different pathogenicity among PCV2 isolates (Grau-Roma et al. 2008; Dupont et al. 2008). The combined effect of these factors might enhance the replication ability of PCV2 resulting in dysfunction of the host immune system and more severe clinical manifestation of the disease (Vincent et al. 2005; Krakowka et al. 2002; Segales et al. 2004b).

After classifying the necropsied pigs into 2 groups according to the PMWS status (as PMWS-affected and non-affected), we were able to carry out additional serological and quantitative PCR analyses from relevant samples. Taking into account the PMWS diagnostic result in individual pigs and the fact that a relationship between the genomic load of PCV2 and the amount of PCV2 antigen detected by IHC within lesions has been established (Brunborg et al. 2004), the high concentration of PCV2 DNA templates observed in the lymph nodes of the necropsied pigs appears to be a good indicator for determination of the PMWS status. We observed that concentrations of PCV2 DNA isolated from lymph nodes of PMWS affected pigs were about 3 logs higher than the levels detected in the second classified group, and this high PCV2 DNA viral loads could be associated with the presence of PMWS lesions.

Our study confirmed the presence of other porcine viruses in 54\% PCV2-positive pigs. Combined infection with PRRSV of the European genotype and PCV2 was found in the lymphoid organs of $31 \%$ pigs out of the 39 examined. Natural occurrence of both viruses in pig herds has been reported previously (Larochelle et al. 1999; Segales et al. 2002) but our study did not confirm PRRSV infection in any of the PMWS-affected pigs. High proportion of natural occurrence of PRRSV infection in the group of PMWS non-affected pigs could be the cause of low findings of actual PMWS cases, as similar clinical manifestations of respiratory diseases and wasting in the categories of young pigs in the course of PRRSV infection could have influenced an adequate selection of pigs for laboratory examinations. Concurrent infection with PCV2 and PPV was confirmed in $23 \%$ of the 39 pigs examined. In contrast to PRRSV infections, the presence of PPV DNA was found in 3 out of 4 PMWS affected pigs. Low concentrations of PPV DNA were confirmed in 6 pigs of the PMWS-non-affected group. The obtained result confirmed previous findings that PPV co-infections with PCV2 could be linked to PMWS not only in 
experimental challenged models (Kennedy et al. 2000; Allan et al. 1999) but also under field conditions (E1lis et al. 2000). However, our results confirmed that concurrent PPV and PCV2 infections in the field do not explain the occurrence of all PMWS cases.

The results of serological examination of blood samples collected during the necropsy of 100 pigs are suggestive of great prevalence of PCV2 infections in pig herds. No antibodies to PCV2 were found in 5 out of 100 serum samples taken from the necropsied pigs. Positive serological findings did not allow determining whether the obtained antibodies were passively acquired maternal antibodies or those induced by PCV2 infection. The wide age range (6 to 12 months) of the laboratory examined pigs indicates both types of PCV2 antibodies. Lower mean level of antibodies to PCV2 was found in the group of 4 PMWSaffected pigs compared to mean level of antibodies in the remaining 96 pigs. A decrease of antibody production in PMWS affected pigs could result from immunosuppression of the immune response during PCV2 infection (Segales and Mateu 2006). However, in our study, differences in PCV2 antibody mean levels among PMWS-classified groups only approach the significant value, most probably due to the small amount of data analysed in the PMWS-affected group. Our serological investigation showed that detection and quantification of ELISA antibodies to PCV2 in serum samples collected from individual pigs at a single point in time had a low value. Although the serological tests are not very reliable in the diagnosis of PMWS, the importance of quantitative serology lies in the possibility of determining the dynamics of PCV2 seroconversion and its relation to the clinical outcome of the infection, as well as in the possibility of assessing the quality of vaccination.

We can conclude that the epidemiological survey provided a more accurate picture of the PMWS/PCVD situation in the Czech Republic and confirmed that PMWS was identified not only at the individual pig level but also at the herd level. Using additional real time PCR techniques revealed possible co-infections of pigs with other infectious agents which might participate in clinical symptoms of PMWS.

\section{Výzkumná epidemiologická studie na infekci cirkoviru prasat typu 2 a syndromu multisystémového chřadnutí selat po odstavu v České republice}

Předmětem naší studie bylo diagnostikovat syndrom multisystémového chřadnutí selat po odstavu (PMWS) s použitím výsledků laboratorního vyšetření ze stovky prasat vykazující chřadnutí, ze 33 chovů prasat a určit rozšíření tohoto onemocnění v České republice ke konci roku 2007. Mikroskopické léze spojené s výskytem antigenů cirkoviru prasat typu 2 (PCV2) byly zaznamenány v mízních uzlinách 39 prasat, z celkových 100 nemocných $(39 \%)$. Na základě mikroskopického vyšetření jednotlivých mízních uzlin obsahujících vysoké množství antigenu PCV2 byl zároveň u 4 z 39 prasat pocházejících ze 3 , z celkových 33 chovů $(9 \%)$ zjištěn syndrom PMWS. Tato epidemiologická studie poukazuje na to, že infekce způsobované PCV2 spojené s onemocněním PMWS, se v České Republice vyskytují pouze sporadicky. Následně použitá metoda real time PCR potvrdila vztah mezi výskytem syndromu PMWS u jednotlivých kategorií prasat a množstvím DNA cirkoviru prasat typu 2. DNA PCV2 obsažená v mízních uzlinách prasat zasažených PMWS byla o 3 řády vyšší, než hladiny zaznamenané u skupiny PMWS nepostižené $(p<0,05)$. Takto vysoké hladiny virové DNA cirkoviru typu 2 pravděpodobně souvisí s výskytem PMWS lézí. U 21 prasat z celkových 39 nakažených cirkovirem typu 2 byly real time PCR metodou zaznamenány paralelně probíhající virové infekce (PRRSV, PPV). Výsledky sérologického vyšetření krevních vzorků, odebraných během pitvy ze stovky prasat, svědčí o vysoké prevalenci infekce PCV2 v chovech prasat, přesto vzorky séra odebrané od jednotlivých prasat ve stejnou dobu, nemají vysokou vypovídací hodnotu. 


\section{Acknowledgement}

This work was supported by the Ministry of Agriculture of the Czech Republic (Projects NPV 1B53016 and MZE0002716201).

\section{References}

Allan GM, McNeilly F, Kennedy S, Daft B, Clark EG, Ellis JA, Haines DM, Meehan BM, Adair BM 1998: Isolation of porcine circovirus-like viruses from pigs with a wasting disease in the USA and Europe. J Vet Diagn Invest 10: 3-10

Allan GM, Kennedy S, McNeilly F, Foster JC, Ellis JA, Krakowka SJ, Meehan BM, Adair BM 1999: Experimental reproduction of severe wasting disease by co-infection of pigs with porcine circovirus and porcine parvovirus. J Comp Pathol 121: 1-11

Allan GM, Ellis JA 2000: Porcine circoviruses: a review. J Vet Diagn Invest 12: 3-14

Brunborg IM, Moldal T, Jonassen CM 2004: Quantitation of porcine circovirus type 2 isolated from serum/ plasma and tissue samples of healthy pigs and pigs with postweaning multisystemic wasting syndrome using a TaqMan-based real-time PCR. J Virol Methods 122: 171-178

Clark EG 1997: Post-weaning multisystemic wasting syndrome. In: P Am Assoc Swine Practitioners 28: 499-501

Dupont K, Nielsen EO, Baekbo P, Larsen LE 2008: Genomic analysis of PCV2 isolates from Danish archives and a current PMWS case-control study supports a shift in genotypes with time. Vet Microbiol 128: 56-64

Ellis J, Hassard L, Clark E, Harding J, Allan G, Wilson P, Strokappe J, Martin K, McNeilly F, Meehan B, Todd D, Haines D 1998: Isolation of circovirus from lesions of pigs with postweaning multisystemic wasting syndrome. Canadian Vet J 39: 44-51

Ellis JA, Bratanich A, Clark EG, Allan G, Meehan B, Haines DM, Harding J, West KH, Krakowka S, Konoby C, Hassard L, Martin K, McNeilly F 2000: Coinfection by porcine circoviruses and porcine parvovirus in pigs with naturally acquired postweaning multisystemic wasting syndrome. J Vet Diagn Invest 12: 21-27

Ellis J, Krakowka S, Lairmore M, Haunes D, Bratanich A, Clark E, Allan G, Konoby C, Hassard L, Meehan B, Martin K, Harding J, Kennedy S and McNeilly F 1999: Reproduction of lesion of postweaning multisystemic wasting syndrome in pigs. J Vet Diagn Invest 11: 3-14

Grau-Roma L, Crisci E, Sibila M, Lopez-Soria S, Nofrarias M, Cortey M, Fraile L, Olvera A and Segales J 2008: A proposal on porcine circovirus type 2 (PCV2) genotype definition and their relation with postweaning multisystemic wasting syndrome (PMWS) occurrence. Vet Microbiol 128: 23-35

Kennedy S, Allan G, McNeilly F, Adair BM, Hughes A, Spillane P 1998: Porcine circovirus infection in Northern Ireland. Vet Rec 142: 495-496

Kennedy S, Moffett D, McNeilly F, Meehan B, Ellis J, Krakowka S, Allan GM 2000: Reproduction of lesions of postweaning multisystemic wasting syndrome by infection of conventional pigs with porcine circovirus type 2 alone or in combination with porcine parvovirus. J Comp Pathol 122: 9-24

Kiss I, Kecskemeti S, Tuboly T, Bajmocy E, Tanyi J 2000: New pig disease in Hungary: Postweaning multisystemic wasting syndrome caused by circovirus. Acta Vet Hung 48: 469-475

Krakowka S, Ellis JA, Meehan B, Kennedy S, McNeilly F, Allan G 2000: Viral wasting syndrome of swine: experimental reproduction of postweaning multisystemic wasting syndrome in gnotobiotic swine by coinfection with porcine circovirus 2 and porcine parvovirus. Vet Pathol 37: 254-263

Krakowka S, Ellis JA, McNeilly F, Ringler S, Rings DM, Allan G 2001: Activation of the immune system is the pivotal event in the production of wasting disease in pigs infected with porcine circovirus-2 (PCV-2). Vet Pathol 38: 31-42

Krakowka S, Ellis JA, McNeilly F, Gilpin D, Meehan B, McCullough K, Allan G 2002: Immunologic features of porcine circovirus type 2 infection. Viral Immunol 15: 567-582

Krakowka S, Ellis J, McNeilly F, Waldner C, Rings DM, Allan G 2007: Mycoplasma hyopneumoniae bacterins and porcine circovirus type 2 (PCV2) infection: induction of postweaning multisystemic wasting syndrome (PMWS) in the gnotobiotic swine model of PCV2-associated disease. Can Vet J 48: 716-724

Kyriakis SC, Saoulidis K, Lekkas S, Miliotis ChC, Papoutsis PA, Kennedy S 2002: The effects of immunomodulation on the clinical and pathological expression of postweaning multisystemic wasting syndrome. $\mathrm{J}$ Comp Pathol 126: 38-46

Larochelle R, Morin M, Antaya M, Magar R 1999: Identification and incidence of porcine circovirus in routine field cases in Quebec as determined by PCR. Vet Rec 145: 140-142

Lecann P, Alabina E, Madec F, Cariolet R, Jestin A 1997: Piglet wasting disease. Vet Rec 141: 660

Lipej Z, Segales J, Toplak I, Sostaric B, Roic B, Lojkic M, Hostnik P, Grom J, Barlic-Maganja D, Zarkovic K, Oraic D 2005: Postweaning multisystemic wasting syndrome (PMWS) in pigs in Croatia: detection and characterisation of porcine circovirus type 2 (PCV2). Acta Vet Hung 53: 385-396

Madec F, Eveno E, Morvan P, Hamon P, Blanchard P, Cariolet R, Amenna N, Morvan H, Truong C, Mahé D, Alabina E, Jestin A 2000: Post-weaning multisystemic wasting syndrome (PMWS) in pigs in France: clinical observations from follow-up studies on affected farms. Livest Prod Sci 63: 223-233

McNeilly F, McNair I, Mackie DP, Meehan BM, Kennedy S, Moffett D, Ellis J, Krakowka S, Allan GM 2001: Production, characterisation and applications of monoclonal antibodies to porcine circovirus 2. Arch Virol 146: $909-922$ 
Onuki A, Abe K, Togashi K, Kawashima K, Taneichi A, Tsunemitsu H 1999: Detection of porcine circovirus from lesions of a pig with wasting disease in Japan. J Vet Med Sci 61: 1119-1123

Opriessnig T, McKeown NE, Harmon KL, Meng XJ, Halbur PG 2006: Porcine Circovirus Type 2 Infection decreases the efficacy of a modified live porcine reproductive and respiratory syndrome virus vaccine. Clin Vaccine Immunol Vol. 13, No. 8: 923-929

Pallares FJ, Halbur PG, Opriessnig T, Sorden SD, Villar D, Janke BH, Yaeger MJ, Larsosn DJ, Schwartz KJ, Yoon KJ, Hoffman LJ 2002: Porcine circovirus type 2 (PCV-2) coinfections in US field cases of postweaning multisystemic wasting syndrome (PMWS). J Vet Diagn Invest 14: 515-519

Pejsak Z, Kolodziejcyk P, Kozaczynski W, Stadejek T, Lipowski A, Roszkowski J 2001: The first report of porcine dermatitis and nephropathy syndrome in a pig farm. Med Weter 57: 591-594

Pogranichniy RM, Yoon KJ, Harms PA, Sorden SD, Daniels M 2002: Case-control study on the association of porcine circovirus type 2 and other swine viral pathogens with postweaning multisystemic wasting syndrome. J Vet Diagn Invest 14: 449-456

Psikal I, Kosinova E, Marcekova Z, Tesarik R, Bendova J 2006: Comparison of two ELISA techniques for monitoring of antibody response to porcine circovirus type 2 in porcine sera. In: Proceedings of the 19th IPVS Congress, Copenhagen, Denmark, p. 82

Quintana J, Segales J, Rosell C, Calsamiglia M, Rodriguez-Arrioja GM, Chianini F, Folch JM, Maldonado J, Canal M, Plana-Duran J, Domingo M 2001: Clinical and pathological observations of pigs with postweaning multisystemic wasting syndrome. Vet Rec 149: 357-361

Rose N, Larour G, Lediguerher G, Eveno E, Jolly JP, Blanchard P, Oger A, Ledimna M, Jestin A, Madec F 2003: Risk factors for porcine post-weaning multisystemic wasting syndrome (PMWS) in 149 French farrow-tofinish herds. Prev Vet Med 61: 209-225

Rosell C, Segales J, Plana-Duran J, Balasch M, Rodriguez-Arrioja GM, Kennedy S, Allan GM, McNeilly F, Latimer KS, Domingo M 1999: Pathological, immunohistochemical, and in-situ hybridization studies of natural cases of postweaning multisystemic wasting syndrome (PMWS) in pigs. J Comp Pathol 120: 59-78

Rosell C, Segales J, Ramos-Vara JA, Folch JM, Rodriguez-Arrioja GM, Duran CO, Balasch M, Plana-Duran J, Domingo M 2000: Identification of porcine circovirus in tissues of pigs with porcine dermatitis and nephropathy syndrome. Vet Rec 146: 40-43

Sarli G, Ostanello F, Morandi F, Fusaro L, Bacci L, Nigrielli A, Alborali L, Dottori M, Vezzoli F, Barigazzi G, Fiorentini L, Sala V, Leotti G 2008: Diagnosis of PMWS in Italy. Large Anim Rev 14: 119-126

Segales J, Sitjar M, Domingo M, Dee S, Del Pozo M, Noval R, Sacristan C, De Las Heras A, Ferro A, Latimer KS 1997: First report of post-weaning multisystemic wasting syndrome in pigs in Spain. Vet Rec 141: 600-601

Segales J, Calsamiglia M, Rosell C, Soler M, Maldonado J, Martin M, Domingo M 2002: Porcine reproductive and respiratory syndrome virus (PRRSV) infection status in pigs naturally affected with post-weaning multisystemic wasting syndrome (PMWS) in Spain. Vet Microbiol 85: 23-30

Segales J, Calsamiglia M, Domingo M 2003: How we diagnose post-weaning multisystemic wasting syndrome. In: 4th International Symposium on Emerging and Reemerging Pig Diseases, Rome, Italy, pp. 149-151.

Segales J, Rosell C, Domingo M 2004a: Pathological findings associated with naturally acquired porcine circovirus type 2 associated disease. Vet Microbiol 98: 137-149

Segales J, Domingo M, Chianini F, Majo N, Dominquez J, Darwich L, Mateu E 2004b: Immunosuppression in postweaning multisystemic wasting syndrome affected pigs. Vet Microbiol 98: 151-158

Segales J, Domingo M 2002: Postweaning multisystemic wasting syndrome (PMWS) in pigs. A review. Vet Quart 24: $109-124$

Segales J, Mateu E 2006: Immunosuppression as a feature of postweaning multisystemic wasting syndrome. Vet J 171: 396-397

Sorden SD 2000: Update on porcine circovirus and post-weaning multisystemic wasting syndrome (PMWS). J Swine Health Prod 8: 133-136

Vincent IE, Carrasco CP, Guzylack-Piriou L, Herrmann B, McNeilly F, Allan GM, Summerfield A, McCullough KC 2005: Subset-dependent modulation of dendritic cell activity by circovirus type 2 . Immunology 115: 388 398

Wallgren P, Hasslung F, Bergstrom G, Linder A, Belak K, Segerstad C, Stampe M, Molander B, Bjonberg Kallay T, Norregard E, Ehlorsson CJ, Tornquist M, Fossum C, Allan GM, Robertsson JA 2004: Postweaning multisystemic wasting syndrome-PMWS: the first year with the disease in Sweden. Vet Quart 26: 170-187

Wang C, Huang TS, Huang CC, Tu C, Jong MH, Lin SY, Lai SS 2004: Characterization of porcine circovirus type 2 in Taiwan. J Vet Med Sci 66: 469-475

Wellenberg GJ, Segales J 2006: Spread of post-weaning multisystemic wasting disease (PMWS) in Europe. Tijdschr Diergeneesk 131: 195-197 
Plate VII

Ficek R. et al.: Exploratory ... pp. 81-90
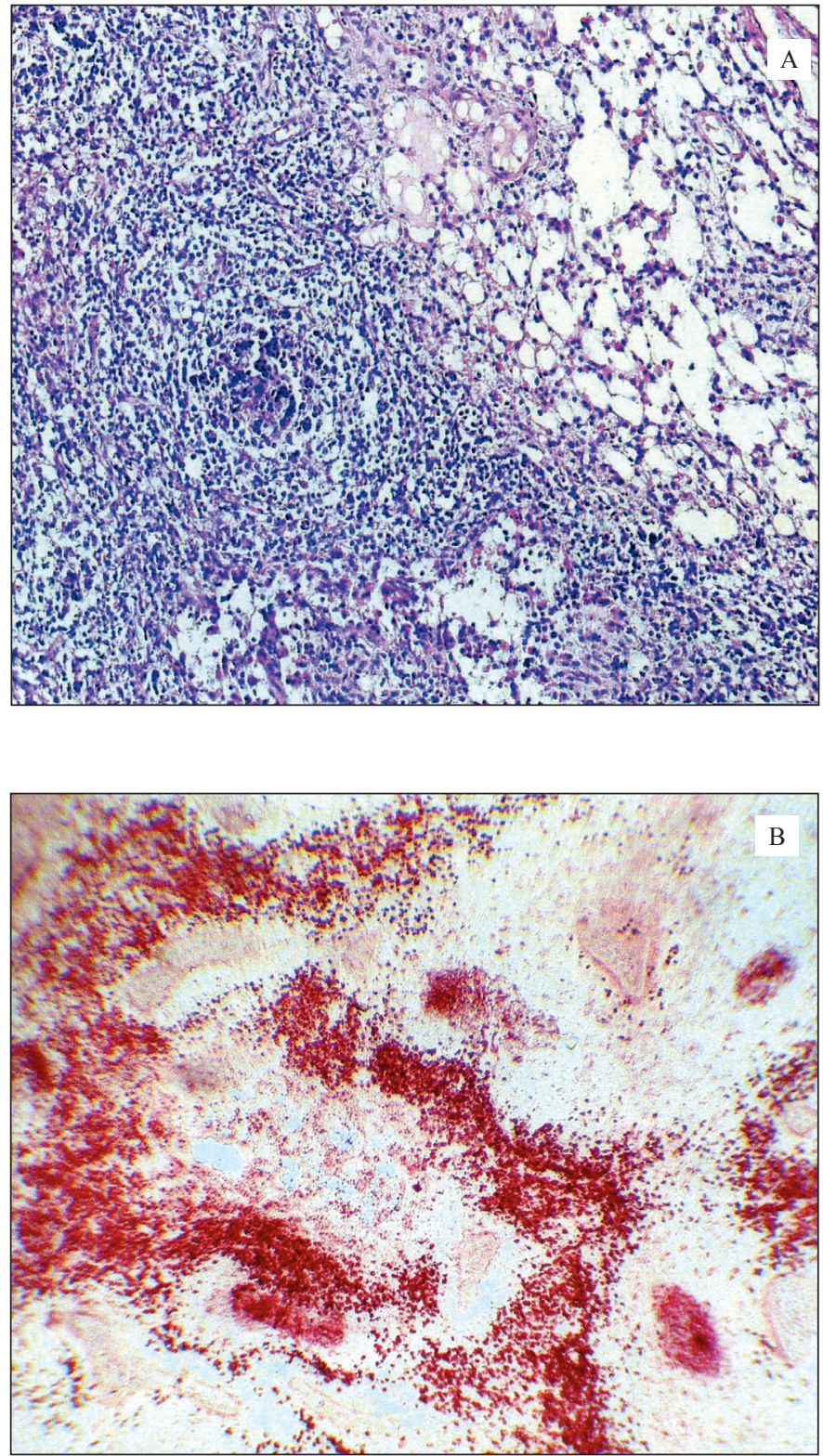

Fig. 1. A) Histopathological examination of lymph node tissue sections stained by HE with severe lesions - granulomatous lymphadenitis with lymphoid depletion and the presence of inclusion bodies. Line segment shows $200 \mu \mathrm{m}$ size.

B) IHC in cryosections of identical lymph node samples indicate large amount of PCV2 antigens. Magnification $\times 200$. 